WOODS HOLE OCEANOGRAPHIC INSTITUTION

Woods Hole, Massachusetts

\author{
SUPPLEMENTARY REPORT ON \\ THE DISTRIBUTION OF SALINITY \\ IN THE ESTUARY OF THE \\ DELAWARE RIVER \\ NYO Exhibit 40A \\ Supplement to NYC Exhibit 40
}

Prepared by

Bostwick H. Ketchum, Scientist in charge July 16, 1953

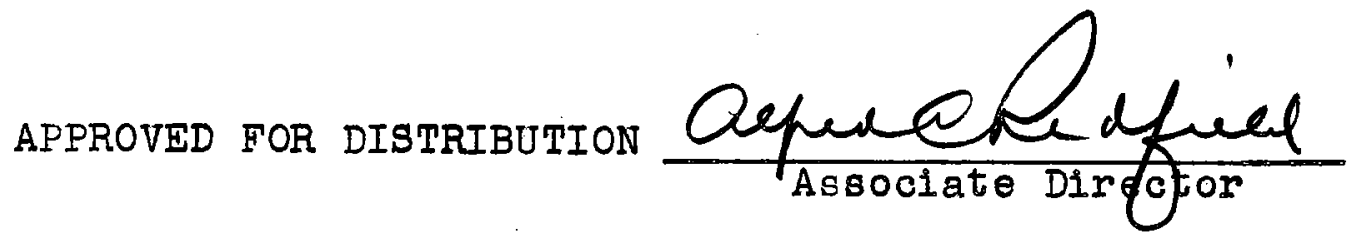


Board of Water Supply

City of New York

120 Wall Street

New York 5, New York

Gentlemen:

At your request I am transmitting herewith a report prepared by Dr. Bostwick H. Ketchum, supplementing our former report on the distribution of salinity in the estuary of the Delaware River, (N. Y. C. Exhibit 40).

This report computes the effect of the Montague Formula upon the salinity of the estuary and compares the results with what would be expected under the original Petition Plan of diversion and release.

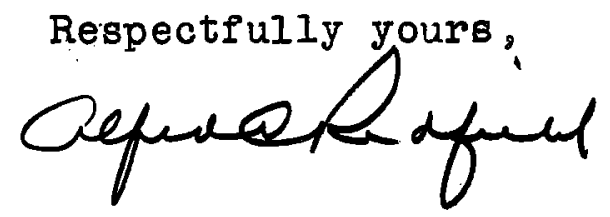

Alfred C. Redifeld Associate Director 
Supplementary report on the distribution of salinity in the estuary of the Delaware River.

Since the preparation of my $r$ eport on the distribution of salinity in the estuary of the Delaware River (N. Y. C. Exhibit 40) a new formula governing the releases of water from storage during periods of low flow has been proposed. The detalls are included in the supplemental testimony of Irving V. A. Huie (Testimony Vol. 4, p. 236-243). I have been asked to determine the effect of releases under this formula. known as the Montague formula, upon the distribution of salinity in the estuary.

Mr. Terenzio has supplied tables of data showing the removal or release of water from the Delaware River averaged over weekly intervals for the years 1930 and 1931. The volume of water available for release will depend, according to the Montague formula, upon the amount of water consumed by the City of New York. Consequently the tables present the effect on the Delaware River Flow for comsumption volumes of $1435,1500,1600$ and $1665 \mathrm{mgd}$. My calculations have been made to show the effects of releases for the lowest and the highest rates of consumption. The former shows the maximum effect, and the latter the permanent effect of this plan. 
Salinity changes would be intermediate for the intermediate values. In addition the effect of releases specified in the original petition proposal have been recalculated, since my original calculations were for a different period of time.

A dry and a wet period, each of four week duration, have been chosen for the purpose of these calculations. The effect of the original petition proposal and of the Montague formula on the flow of the Delaware River at Trenton are shown below:

\section{Table I}

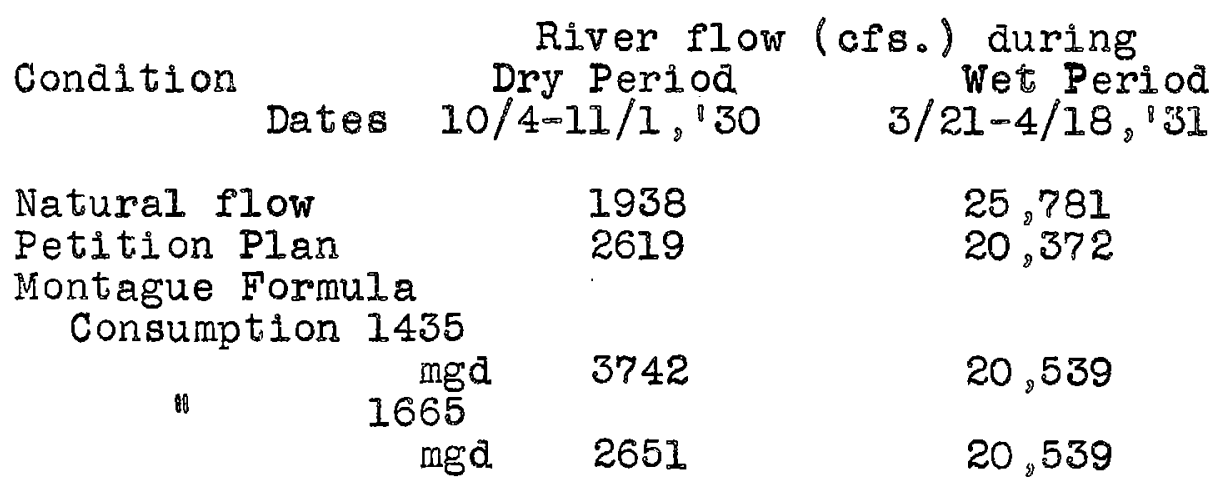

During the dry period the releases of water will Increase the flow in the Delaware River at Trenton. The greatest increase will be obtained when the consumption of water by New York City 1, low. When this reaches the maximumallowed by the Montague 
Formula, the release of water to the river is nearly the same as would be provided under the Petition Plan. During the high flow period, retention of water in the reservoir will reduce the flow in the Delaware River at Trenton. The degree of reduction in flow, for this period of time at least, is somewhat Iess under the Montague Plan than under the original Petition Plan.

The average salinities to be expected in various reaches of Delaware River and Bay have been computed by utilizing these river flow data and the constants derived in my original report (N, $Y$. C. Exhibit 40, p. 34). The predicted salinities are shown in Tables II and III.

During the perlod of low river flow, the unusually high salinities of the estuary will be reduced because of the releases of water, as explained in my original report. The effect of the releases specified in the original Petition Plan, and those called for by the Montague Formula after consumption of $1665 \mathrm{mgd}$. has been reached are virtualiy identical (Table II). All of the differences are less than one tenth of a part per thousand which is much less than the error inherent in the data and consequently in the method of prediction. During the transition period, however, 
when consumption is low and greater releases are provided, significant additional changes in salinity will be produced. When consumption is $1435 \mathrm{mgd}$. the unusually high salinities resulting from low river flow will be reduced by as much as $2.49 \%$, a reduction more than twice as great as that provided by the Petition Plan or by the Montague Plan after maximum consumption has been $r$ eached.

During the period of high river flow, unusually low salinities will be expected in the estuary under natural conditions. The effects of retention of water for storage and use will increase these low salinities, as shown in Table III. The slight differences in salinity calculated for the retention provided by the Petition Plan and by the Montague Formula do not exceed the ten percent limit of error given in the original report for the prediction (N. Y. C. Exhibit 40, Figure 10). It is therefore concluded that, at high rates of river flow, the distribution of salinity in the estuary to be expected as a result of the operation of the Montague Plan will not be significantly different from that which would have been produced by the original Petition Plan.

As discussed in my original report, the proposed diversions and releases of water will decrease 
the range of variation of salinity throughout the estuary. The Montague Formula w1ll increase the degree of stabilization of salinity during the period when the consumption of water is less than the maximum allowed, because of the effect of the greater releases of water during periods of low rates of flow. The ranges of salinity variation expected in various parts of the estuary with unmodified flow, and the flow as modified by the Montague Formula under minimum and maximum consumption conditions are given in Table IV. The variation predicted for unmodified flow at Trenton is slightly different from those predicted in the original report, since different river flows have been used in the two computations. The range of variation will be reduced by the diversion and releases of water provided for in the Montague Formula. The maximum effect is obtained while the consumption of water by the City of New York is at the lower value. The range of variation predicted when consumption reaches $1665 \mathrm{mgd}$. is virtually the same as that given in the original report for the Petition Plan.

From these calculations it is concluded that 
the application of the Montague Formula for diversion and release of Delaware River water will ultimately produce distributions of salinity in the estuary virtually identical with those predicted for the Petition Plan. During the period when the consumption of water by New York City is less than the maximum allowed under the formula, additional regulation will be provided by the release of greater volumes of water during periods of low river flow. These adaltional releases will decrease the unusually high salinities to a greater extent than was provided under the original Petition Plan. When the river flow is great, both the Montague Formula and the original Petition Plan are expected to produce approximately equal effects on the salinity of the estuary, regardless of the consumption rate within the specified limits. 


\section{Table II}

Effects of releases of water on the mean salinity (parts per thousand) to be expected in various reaches of the Delaware River and Bay at low river flow.

\begin{tabular}{|c|c|c|c|c|c|c|c|}
\hline \multirow{3}{*}{$\begin{array}{l}\text { River Flow } \\
\text { Trenton, cfs. } \\
\text { Location }\end{array}$} & \multirow{3}{*}{$\begin{array}{c}\text { No } \\
\text { Diversion } \\
1938 \\
\text { Salinity }\end{array}$} & $\begin{array}{l}\text { Petit } \\
\text { PIE }\end{array}$ & $\begin{array}{l}\text { tion } \\
\text { an }\end{array}$ & Use of 1 & $\begin{array}{l}\text { Montague } \\
435 \mathrm{mgd} \text {. }\end{array}$ & \multicolumn{2}{|c|}{$\begin{array}{l}\text { Formula } \\
\text { Use of } 1665 \mathrm{mg}\end{array}$} \\
\hline & & 261 & & 37 & & & 2651 \\
\hline & & Salinity & Change & Salinity & Change & Salinity & Change \\
\hline $\begin{array}{l}100-200 \\
200=250 \\
250=300 \\
300=350 \\
350=400 \\
400=450 \\
450=500 \\
500=550\end{array}$ & $\begin{array}{r}4.72 \\
10.56 \\
16.93 \\
22.75 \\
26.04 \\
28.92 \\
30.50 \\
31.55\end{array}$ & $\begin{array}{r}4.21 \\
9.56 \\
16.13 \\
21.98 \\
25.54 \\
28.53 \\
30.32 \\
31.42\end{array}$ & $\begin{array}{l}-0.51 \\
-1.00 \\
-0.80 \\
-0.77 \\
-0.50 \\
-0.39 \\
-0.18 \\
-0.13\end{array}$ & $\begin{array}{r}3.51 \\
8.07 \\
14.76 \\
20.82 \\
24.53 \\
27.93 \\
30.04 \\
31.14\end{array}$ & $\begin{array}{l}-1.21 \\
-2.49 \\
-2.17 \\
-1.93 \\
-1.51 \\
-0.99 \\
-0.46 \\
-0.41\end{array}$ & $\begin{array}{r}4.20 \\
9.52 \\
16.10 \\
21.95 \\
25.48 \\
28.50 \\
30.32 \\
31.40\end{array}$ & $\begin{array}{l}-0.52 \\
-1.04 \\
-0.83 \\
-0.80 \\
-0.56 \\
-0.42 \\
-0.18 \\
-0.15\end{array}$ \\
\hline
\end{tabular}


Table III

Effects of diversions of water on the mean salinity (parts per thousand) to be expected in various reaches of the Delaware River and Bay at high river flow.

\begin{tabular}{|c|c|c|c|c|c|c|c|}
\hline $\begin{array}{l}\text { River } \\
\text { Trent }\end{array}$ & $\begin{array}{l}r \text { Flow } \\
\text { ton, cfs. }\end{array}$ & $\begin{array}{c}\text { No } \\
\text { Diversion } \\
25781\end{array}$ & \multicolumn{2}{|c|}{$\begin{array}{l}\text { Petition } \\
\text { Plan }\end{array}$} & \multicolumn{3}{|c|}{$\begin{array}{l}\text { Montague Formula } \\
\text { of } 1435 \text { or } 1665 \text { mgd. }\end{array}$} \\
\hline Locat & tion & Salinity & Salinity & Change & & Salinity & Change \\
\hline $\begin{array}{l}100- \\
200- \\
250= \\
300- \\
350- \\
400= \\
450= \\
500-\end{array}$ & $\begin{array}{l}-200 \\
-\quad 250 \\
-\quad 300 \\
-\quad 350 \\
-\quad 400 \\
-\quad 450 \\
-\quad 500 \\
-550\end{array}$ & $\begin{array}{r}0.09 \\
0.29 \\
3.00 \\
7.03 \\
11.28 \\
18.39 \\
24.89 \\
26.46\end{array}$ & $\begin{array}{r}0.23 \\
0.64 \\
4.45 \\
9.20 \\
13.61 \\
20.34 \\
26.13 \\
27.62\end{array}$ & $\begin{array}{l}+0.14 \\
+0.35 \\
+1.45 \\
+2.17 \\
+2.33 \\
+1.95 \\
+1.24 \\
+1.16\end{array}$ & & $\begin{array}{r}0.22 \\
0.63 \\
4.39 \\
9.10 \\
13.55 \\
20.28 \\
26.07 \\
27.58\end{array}$ & $\begin{array}{l}+0.13 \\
+0.34 \\
+1.39 \\
+2.07 \\
+2.27 \\
+1.89 \\
+1.18 \\
+1.12\end{array}$ \\
\hline
\end{tabular}




\section{Table IV}

Range of variation of salinity (parts per thousand) to be expected in various reaches of the

Delaware River and Bay.

\begin{tabular}{crcc} 
Location & No & \multicolumn{2}{c}{ Montague Formulà } \\
& Diversion & use 1435 mgd. & use 1665 mga. \\
$100-200$ & 4.63 & 3.29 & 3.98 \\
$200-250$ & 10.27 & 7.44 & 8.89 \\
$250-300$ & 13.93 & 10.37 & 11.71 \\
$300-350$ & 15.72 & 11.72 & 12.85 \\
$350-400$ & 14.76 & 10.98 & 11.93 \\
$400-450$ & 10.53 & 7.65 & 8.22 \\
$450-500$ & 5.61 & 3.97 & 4.25 \\
$500-550$ & 5.09 & 3.56 & 3.82
\end{tabular}

